\title{
Resenha do Livro: Capitalismo, Estado e Educação. Carlos Lucena (Org.). Campinas: Alínea, 2008, 217 p.
}

\section{Resenhada por: Andréia Farina de Faria andreiaffaria@hotmail.com}

O livro organizado pelo cientista social, Doutor em Filosofia e História da Educação Carlos Alberto Lucena reune discussões que problematizam as novas configurações do Estado Nação e suas influencias sobre a Educação no capitalismo. A partir dos artigos reunidos o livro consegue elucidar as palavras do organizador de que luta de classes não é uma invenção intelectual, ela é manifestação das contradições de seu tempo (p.7).

No primeiro capítulo, Olinda Maria Noronha recupera as origens históricas do processo de globalização no capitalismo para realizar a crítica a concepções que limitam a globalização a um fenômeno emergente da sociedade capitalista atual. Para a autora, é um processo que se confunde com a expansão do modo de produção capitalista e que dialeticamente assume novas potencialidades na sua forma desenvolvida; ao limitar a análise sobre a globalização como fenômeno atual, negligenciaríamos as mutações da acumulação de capital. O artigo perpassa pelas fases de desenvolvimento das forças produtivas para atualizar as transformações ocorridas no processo de trabalho e o movimento dos organismos internacionais que promovem reformas educacionais de cunho pragmático e utilitarista em atendimento a lógica de mercado.

No segundo capítulo, as autoras Lucília e Janaína Machado destacam a capacidade do capital apropriar-se, mediante a intensificação da globalização, de condições favoráveis a sua expansão colonizando países pobres. O meio ambiente e a educação são terrenos dessa ofensiva, visto que o primeiro é matéria prima da produção e nicho de mercado a partir da própria destruição provocada pelo capital, e a segunda é orientada em consonância com a ideologia dominante. A relação homem/natureza e a formação humana encontram-se, em certa medida, condicionadas no sistema vigente.

No capítulo três, José Luís Sanfelice demonstra que o projeto da burguesia consolidou-se com a formação do Estado Nação, numa época de triunfo liberal (p.69) num movimento de expansão e exploração do centro para a periferia. Os níveis de desenvolvimento da ciência e tecnologia são visivelmente perceptíveis na divisão internacional do trabalho. A educação sofre as interferências das transformações do Estado Nação correspondente à uniformização/hegemonização dos valores capitalistas, ou seja, a educação não escapa da produção e reprodução do capital visto que permanecem intactas as determinações estruturais fundamentais da sociedade (p.80).

No quarto capítulo, Lucena articula a análise marxiana sobre as crises cíclicas do capitalismo - superprodução e tendência decrescente da taxa de lucros - para fundamentar a supremacia do valor de troca sobre o valor de uso na sociedade do capital apontando o papel desempenhado pela ciência e tecnologia nesse processo. O autor, de forma propícia, retoma Mészáros para problematizar o atual estágio de controle do Estado sobre a ciência e cientistas, subordinados as condições instrumentais e institucionais de trabalho (p.92). Como bem afirma Lucena, não se trata de negar a ciência, mas questionar até que ponto a humanidade conseguirá viver com a sua disfunção?

No capítulo intitulado "La precariedad como paradigma de la reestructuración capitalista em la fase de la crisis estructural", Luciano Vasapollo exemplifica as formas de 
superexploração e precarização do trabalho intensificadas pelo crescente nível de desemprego. É fundamental no sentido de entender qual é o significado da reestruturação e a resultante deste processo para os trabalhadores, principalmente nas regiões periféricas onde o capital implementa as piores condições de trabalho.

No capítulo "Riqueza e Miséria do Trabalho no Brasil" Ricardo Antunes reuni de forma rica as tendências da reestruturação produtiva no Brasil a partir de estudos setoriais realizados por diversos pesquisadores. Além dos imperativos tecnológicos e organizacionais que regem as estratégias de acumulação no contexto neoliberal, o texto nos atenta para questões que parecem superadas no mundo trabalho, tal qual o trabalho infantil e desregulamentado que aparecem no bojo da reestruturação.

No sétimo capítulo, Antonio Bosco de Lima aponta que o Estado apresenta um modelo de acordo com o que se define ser sua função. O nível de intervenção do Estado por exemplo, em situações de crise - indica se esse modele é mais, menos ou nenhum mercado (p. 133). O autor retrata a atuação política-econômica estatal do modelo liberal clássico ao keynesianismo, chegando ao Estado neoliberal, por fim traça a crítica marxista no qual o Estado interfere na luta de classes a favor da classe dominante. Nesse sentido, as políticas sociais são uma forma de atenuar as desigualdades e conter grandes movimentações sociais. O controle social sobre as políticas públicas é um direito garantido pela constituição de 1988, mas não é a realidade que vivenciamos. Bosco atribui à indefinição da educação como aspecto crucial nesse processo, ou seja, não se trata de uma crise na educação, mas sobretudo da necessidade de uma ressignificação da forma de tratamento dos conteúdos escolares. Contrasta-se assim a educação como aparelho de estado, sem perder de vista sua dimensão libertadora.

No capítulo "O trabalho como princípio da dignidade da pessoa humana", Robson Luiz de França destaca que o valor da pessoa humana, de caráter universal está vinculado a cidadania. Por sua vez, a noção de cidadania é um mecanismo de legitimação da atuação do Estado que se fundamenta na busca de viabilizar direitos básicos aos cidadãos, o que entendemos por uma concepção de cidadania baseada em um processo político, social e histórico (p.154). Na década de 1990, a construção do Estado mínimo assume seu caráter mais político-ideológico, na qual a educação é o elemento chave desse processo, evidenciada na educação profissional, altamente instrumentalizada no intuito de adequar a educação profissional (já excludente) à modernização do país. Nesse sentido, trabalho e educação, duas condições da cidadania humana passam a ser meios propícios à transmissão dos princípios doutrinários neoliberais. A preocupação do autor está justamente nessa adequação bem como nas formas de resistir a esse processo.

No nono capítulo, "O Estado e o mundo do trabalho em mutação", Maria Vieira Silva se debruça sobre a relação entre Estado-Nação e as ações do terceiro setor no campo da educação. A autora diagnostica que durante a década de 1990, a ação empresarial na organização da escola ultrapassa a forma objetiva de gestão escolar, carregando forte conteúdo ideológico, de captura subjetiva do trabalhador, abrindo espaço para atuação propositiva do terceiro setor. O problema central está no argumento de que o terceiro setor é um espaço político de ruptura da cidadania e dos direitos públicos historicamente conquistados, o que leva Vieira defender uma concepção crítica da educação, que extrapole o conhecimento oficial em atendimento aos interesses daqueles que historicamente ficaram à margem dos bens sociais e materiais que ajudaram a produzir para a humanidade.

No último capítulo do livro, intitulado "Entre o real e o virtual", ao discutir o processo de reforma sindical e trabalhista, Andréia Galvão demonstra a lógica que rege as 
tendências das mudanças e as reformas promovidas no governo Lula. A autora argumenta que a abstenção da lei é uma forma de intervenção estatal que deixa aos "atores" encontrarem seu ponto de "equilíbrio"(p.203). Quanto a esse aspecto, a desregulamentação e flexibilização da legislação do trabalho são parte da estratégia do capital mundializado com o objetivo de criar novas formas de contratos que fogem dos direitos sociais historicamente conquistados pelos trabalhadores. O governo Lula tem mantido ainda que de forma diferenciada a flexibilização trabalhista iniciada no governo FHC; que agora ocorre de forma pontual e silenciosa, ou seja, é um governo que também não está comprometido em ampliar, tampouco assegurar os direitos trabalhistas. Já a reforma sindical avança lentamente, pois divide os diferentes atores sociais. $\mathrm{O}$ ponto alto dessa discussão é a inversão de papéis causados pelo capital, no qual o trabalhador passa a ser culpado e punido pelo desemprego estrutural gerado por outrem.

Percebemos ao longo dos capítulos que o livro representa um instrumento crítico para profissionais de diversas áreas e demais interessados em refletir sobre as relações sociais sob a égide do capital. 